\title{
Conditions for Peaceful Resolution in Territorial Disputes of Northeast Asia
}

\author{
Woondo Choi \\ (N ortheast Asian H istory Foundation)
}

\section{$\langle$ CONTENTS〉}

I. Introduction

II. Literature Review

III. Initiation, Escalation and Peaceful

Resolution of Territorial Disputes

1. Variables

2. International Political Factors

3. International Experience Factors in Domestic Context

4. Domestic Variables in the Democratic Peace Thesis
5. Variables Concerned with Peaceful Resolution

IV. Test on Territorial Matters in

Northeast Asia

1. Case 1: Dokdo/Takeshima

2. Case 2: Senkaku/Diaoyutai Islands

3. Case 3: Northern Territories of Japan

V. Conclusion

- Keywords : territorial dispute, alliance, democratic peace, dispute initiation, dispute escalation, peaceful resolution, Dokdo/Takeshima, Senkaku/ Diaoyutai, Northern territories of Japan

\section{【ABSTRACT】}

This paper reviews previous the empirical analyses on territorial disputes of the world over the last century to list the variables found statistically significant and to introduce the hypotheses deduced from theoretical perspectives explaining various dimensions of territorial dispute. The variables and hypotheses are tested for their validity against the three territorial disputes of Northeast Asia. The cases of Dokto/Takeshima, Senkaku/Diaoyutai, and Northern territories of Japan are evaluated based upon the findings of the studies. Policy suggestions for the Dokdo/Takeshima case are followed according to the variables.

At the domestic level, the promotion of democracy will contribute to the peaceful settlement of the dispute, and signaling a firm resolve in a crisis situation is

* This paper does not represent the official position of the Northeast Asian History Foundation. Any errors or omissions are the responsibility of the author. 
important in preventing the escalation of the dispute into an armed conflict. At the international level, alliance ties with the United States acted as a deterrent against dispute escalation between Japan and Korea, and maintaining a balance in military forces contribute to peaceful resolution of the dispute. If a regional security community is developed, which does not exist in Northeast Asia, it will make a most comprehensive influence for peaceful resolution on the whole life cycle of territorial dispute.

\section{Introduction}

The discipline of international relations aims to find the general rules governing the relations between and among countries. To confirm the theoretical validity of any finding, the finding must be tested against actual cases. This study applies the findings on the factors affecting the initiation, escalation, and peaceful resolution of territorial disputes to actual cases of territorial matters in Northeast Asia.

Statistical surveys illustrate that territorial disputes are the most common causes of interstate war, even though colonial competition is now over and so is the Cold War.' This means that territorial disputes should be a major theme in the study of war and conflict. According to Huth, between 1945 and 1990, there were 129 territorial disputes. Among them, 60 had not been resolved and were ongoing as of 1995. During the same period, there were 21 interstate wars. Nineteen of them were taking place outside Europe, and in 14 cases, territorial disputes were the direct causes of the armed conflicts. In the meantime, about a half of the territorial disputes did not involve the threat or use of military force. Fifty-three (41 percent) cases were settled peacefully by the challenger through compromise or conciliation, while 57 (44 percent) cases stalemated and 19 (15 percent) were settled on terms favorable to the challenger - that is, occupation or capitulation of the target. ${ }^{2)}$

1) See Paul K. Huth and Todd Allee, The Democratic Peace and Territorial Conflict in the Twentieth Century (New York: Cambridge University Press, 2002a); John A. Vasquez, "Mapping the Probability of War and Analyzing the Possibility of Peace: The Role of Territorial Disputes," Conflict Management and Peace Science 18-2 (2001), pp. 145-73; John A. Vasquez, The War Puzzle (Cambridge: Cambridge University Press, 1993); Nils P. Goertz and Paul Diehl, Territorial Changes and International Conflict (London: Routledge, 1992); Dan Smith, "Trends and Causes of Armed Conflicts," (Berghof Foundation, 1999), www.berghofhandbook.net/articles/smith_handbook.pdf. 
Currently, there are three major territorial disputes underway in Northeast Asia. Korea, China and Russia are each involved in a dispute with Japan over territorial sovereignty. This article evaluates the status of these three territorial disputes against variables considered decisive in the development of territorial disputes around the world over the last century. After addressing the current state of the art by reviewing major arguments on this topic, findings of the empirical studies are summed up by introducing the statistically significant variables. The three disputes of Northeast Asia are evaluated within this framework, with the aim of formulating policy options for their peaceful resolution.

\section{Literature Review}

After the end of the Cold War, which had divided the world into two camps engaged in continuous armed and unarmed conflicts, peace was expected to dominate world affairs. Contrary to expectations, however, conflicts erupted in numerous locations around the world. Until then, the study of international relations focused only on major power relations and neglected territorial disputes prevalent outside Europe and North America. ${ }^{3)}$ Paul Huth's work, published in 1988, introduced the statistical method of Logistical Analysis, applicable to binominal dependent variable. ${ }^{4)}$ Subsequent works, whose aims have been to pinpoint the determinant causes of a dispute's progress into either peaceful resolution or armed conflict, have benefited greatly from Huth's methodological breakthrough and have used Logit analysis or Probit analysis to handle binominal or trinominal dependent variables.

During the 1980s, while the debate between (neo)realism and (neo)liberalism dominated the study of war and peace, there was an area of research that began to garner increasing attention: the decision-making process. In the 1990s, such developments led to an adherence to realist explanations and a focus on domestic political processes in the study of territorial disputes. Huth incorporated domestic variables as supplementary explanations to realist variables. ${ }^{5)}$ The variables in the international context are understood as being processed in the domestic political arena and they are replaced by variables which can reflect domestic process more directly.

2) Paul K. Huth, Standing Your Ground: Territorial Disputes and International Conflict (Ann Arbor: Michigan University Press, 1998).

3) Huth (1998), chap. 1.

4) Paul K. Huth, "Extended Deterrence and the Outbreak of War," American Political Science Review 82-2 (1988), pp. 423-43.

5) Huth (1998). 
In the 1990s, many scholars delved into a theoretical investigation of the democratic peace thesis, ${ }^{6}$ which is known as the only law-like finding in the study of international relations. They laid out theoretical perspectives that supplemented rather than conflicted with the realist outlook. Pointing to the limitations in realism's structural approach, Bueno de Mesquita proclaimed, "It is time to bring the study of citizens, leaders, and leadership back to the forefront... Without bringing leaders and their domestic incentives back to the forefront of our research, I believe that we cannot really hope to understand the motivations and constraints that shape international politics and economics, the very factors we hope to explain." "Huth and Allee incorporated into to the realist model the variables deduced from the democratic peace thesis, such as regime type and variables concerned with political leadership. ${ }^{8}$

More recently, alternative perspectives on territorial disputes have surfaced, including one held by Gibler. ${ }^{9)}$ Gibler argues that democratic peace, considered as an empirical law, is only a spurious relationship between democracy and peace. When a country does not perceive territorial threat and does not have plans to alter the status quo, we can say its border relations are stable. Under such circumstances, the country does not need to protect territorial borders and maintain standing armies. External threat makes the domestic order and control inevitable for political leaders and the situation militates against establishment of democratic rules in domestic politics. Stable border relations are one of the major factors that lower the probability of territorial disputes and makes democracy possible. In turn, democratic countries do not have border disputes. Democracies do not fight democracies.

The perspectives of $\mathrm{Tir}^{10)}$ and $\mathrm{Smith}^{11)}$ comprise the second group of examples. They argue that although peaceful and agreed-upon changes do not guarantee peaceful

6) R. J. Rummel, "Libertarianism and International Violence," Journal of Conflict Resolution 27-1 (1983), pp. 27-71; Michael Doyle, "Liberalism and World Politics," American Political Science Review 80-4 (1986), pp. 1151-61; Zeev Maoz and Bruce Russett, "Normative and Structural Causes of Democratic Peace, 1946-1986," American Political Science Review 87-3 (1993), pp. 62438; Bruce Bueno de Mesquita and David Lalman, War and Reason (New Haven: Yale University, 1992); and Bruce Bueno de Mesquita, Alastair Smith, Randolph Siverson, and James D. Morrow, Logic of Political Survival (Cambridge: MIT Press, 2003) are the examples.

7) Bruce Bueno de Mesquita, "Domestic Politics and International Relations," International Studies Quarterly 46-1 (2002), p. 4.

8) Paul K. Huth and Todd Allee, "Domestic Political Accountability and the Escalation and Settlement of International Disputes," Journal of Conflict Resolution 46-6 (2002b), pp. 754-90.

9) Douglas M. Gibler, "Bordering on Peace: Democracy, Territorial Issues, and Conflict," International Studies Quarterly 51 (2007), pp. 509-32.

10) Jaroslav Tir, Redrawing the Map to Promote Peace: Territorial Dispute Management via Territorial Changes (Lanham: Lexington Books, 2006). 
outcomes in every case, researchers find it tempting to draw correlations between them. Compared to territorial changes that result from peaceful developments, territorial changes resulting from armed conflicts are more likely to be followed by armed conflicts as the party on the losing end would be inclined to fight to recover the lost territory. If the transfer of territory occurs under a violent conflict, the loser may claim that the transference is null and void. Whether peaceful or violent, not all disputes end with an agreement between the challenger and the target.

Now, we need to clarify the concept of dispute. Territorial disputes are disagreements over territorial control. Even a simple discrepancy in the statements concerned with the ownership of a particular piece of land, without armed conflict, can be called a "territorial dispute." As in the diagram below, a dispute event can be divided into four conceptual stages: peaceful resolution (compromise or conciliation), ongoing dispute without armed conflict, armed conflict, and interstate war. As long as a dispute can be contained so that it does not escalate into an armed conflict-which has the possibility of erupting into war - it can be said that we are in a state of peace.

Figure 1. Life Cycle of a Dispute

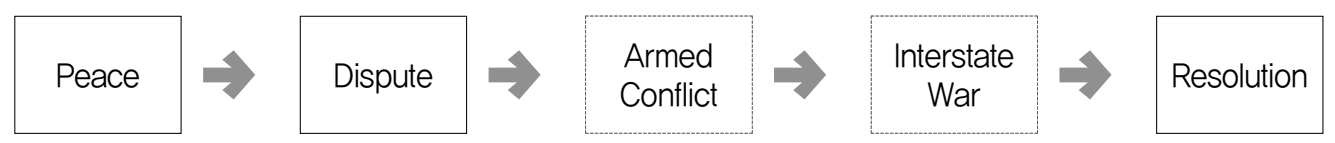

Each case of dispute and conflict can be analyzed in the framework of a cycle in the above diagram but it is possible only on the conceptual level. ${ }^{12)}$ In reality, it is very rare for a dispute to develop or proceed in the order of the clearly demarcated stages. In Northeast Asia, interstate disputes have occurred repetitively, and each case has exhibited a cyclical trend, with ups and downs at relatively regular intervals. It is not easy to pinpoint the challenger and target for each case. Rather, the unit of analysis should be one episode of dispute, and the "challenger" would be the party that initiated the episode.

11) Smith (1999).

12) The difficulties in conceptual identification of the life cycle of dispute is well-illustrated in Ko Sangdoo, Choi Woondo, and Yoon Taeyoung, "Conflict Management in the Post-Cold War Era: Preventive Diplomacy and PKO,” The Korean Journal of Defense Analysis 17-2 (2005), pp. 35-62. 


\section{Initiation, Escalation and Peaceful Resolution of Territorial Disputes}

\section{Variables}

In studying the disputes over the islands in Northeast Asia, we are interested with when the disputes will recur (or past instances), how serious they will be, and how they can be settled without armed conflict. To apply the findings of current research to territorial disputes in Northeast Asia, we first need to discuss the relevant findings.

Huth $^{13)}$ and Diehl ${ }^{14)}$ listed the variables that were hypothesized to affect the initiation, escalation, and resolution of territorial disputes. Table 1 is based on the variables proposed in the previous studies. ${ }^{15}$ ) Table 1 distinguishes two groups of variable into "international political factors" and "international experience factors." The former group is enlisting the structural determinants, mentioned in the realist perspective, and the latter is enlisting the events experienced and remembered variably in each country.

Table 1. Summary of Statistical Analyses

\begin{tabular}{lccc}
\hline \multicolumn{1}{c}{ Explanatery Variables } & $\begin{array}{c}\text { Dispute } \\
\text { Initiation }\end{array}$ & $\begin{array}{c}\text { Dispute } \\
\text { Escalation }\end{array}$ & $\begin{array}{c}\text { Peaceful } \\
\text { Resolution }\end{array}$ \\
\hline Economic value of territory & International Political Factors & & \\
Strategic location of territory & + & + & - \\
Balance of military forces & +++ & +++ & --- \\
Deterrent alliance ties & +++ & +++ & --- \\
Common security ties & & - & \\
Prior settlement & --- & --- & +++ \\
\hline
\end{tabular}

International Experience Factors in Domestic Context

Disputes with third parties

Stalemates in negotiations

Change in status quo

Defeat in armed conflict

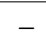

$-$

$+++$

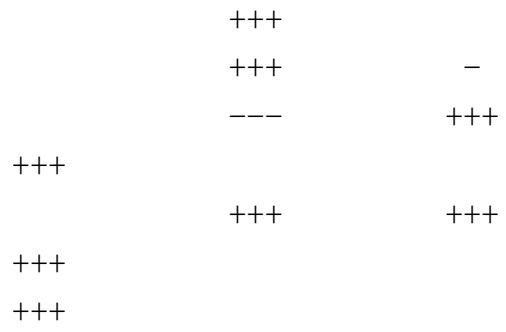

Prior unsettled dispute

Prior military conflict

Prior loss of territory

Decolonization norms
13) Huth (1998).

14) Paul F. Diehl (eds.), A Road Map to War: Territorial Dimensions of International Conflict (Nashville: Vanderbilt University Press, 1999). 


\begin{tabular}{lccc}
\hline \multicolumn{1}{c}{ Explanatory Variables } & $\begin{array}{c}\text { Dispute } \\
\text { Initiation }\end{array}$ & $\begin{array}{c}\text { Dispute } \\
\text { Escalation }\end{array}$ & $\begin{array}{c}\text { Peaceful } \\
\text { Resolution }\end{array}$ \\
\hline Political Accountability Factors & & \\
\hline $\begin{array}{l}\text { Challenger democracy level } \\
\text { Target democracy level }\end{array}$ & --- & -- & \\
Target Democracy $\times$ Signal of Resolve & & -- & +++ \\
Strength of the challenger ruling coalition & -- & +++ & +++ \\
Months since elections in challenger & --- & - & --- \\
Months since elections in target & Dispute & Dispute & Peaceful \\
\hline Explanatory Variables & Initiation & Escalation & Resolution \\
\hline
\end{tabular}

,+- : included in the equation but statistically insignificant

,+++--- : statistically significant and important marginal impact

\section{International Political Factors}

Statistical analyses demonstrate that the strategic location of territory has a major impact on the initiation of territorial dispute while economic value has only a minimal impact. Security concerns may dominate the calculations of decision makers in territorial disputes. In the sense of issue salience also, territorial disputes surpass maritime issues and river claims in their tangible and intangible salience. ${ }^{16)}$ While tangibility focuses more on economic values of an asset, intangible value is made up of historical memories and strategic utility. A piece of land is intangibly-valued when it is thought to be integral to the national identity and cannot be replaced by any other piece of land. Tir argues that intangibly-valued lands appeal to a broader population of the electorate than tangibly-valued lands do. He goes on to maintain that the former provides greater chances of payoff to the leaders who claim sovereignty over them. ${ }^{17}$

Relative military capability is another important variable for all three policy decisions of initiation, escalation, and concession. ${ }^{18)}$ For the challenger, the military advantage raises the probability of initiating disputes and escalating them into armed conflicts. For

15) See Huth (1998), p. 65; Huth and Allee (2002b), pp. 754-90; Giacomo Chiozza and Ajin Choi, "Guess Who Did What: Political Leaderships and the Management of Territorial Disputes, 1950-1990," Journal of Conflict Resolution 47-3 (2003), pp. 251-78; and Paul R. Hensel, Sara M. Mitchell, Thomas E. Sowers II, and Clayton L. Thyne, "Bones of Contention: Comparing Territorial, Maritime, and River Issues," Journal of Conflict Resolution 52-1 (2008), pp. 117-43.

16) Hensel et al. (2008), pp. 117-43.

17) Tir (2006).

18) Huth and Allee (2002b); Hensel et al. (2008). 
the target country, the advantage lowers the probability of making concessions or opting for negotiations. Looking into cases in which the weaker states are not deterred from initiating disputes, Huth concluded that the initiators are making claims over colonial or overseas territory of the target state, expecting domestic and international support for the demand, whose legitimacy derives from decolonization norms. ${ }^{19)}$

The alliance relationship between the challenger and the target is found to have a considerable influence in keeping the decision maker from getting his/her respective country involved in disputes. Security concern that is the major reason for the alignment may militate against the initiation of disputes over relatively less important political interests. If a dispute is initiated, this alliance relationship plays an important role in keeping the dispute from escalating into an armed conflict.

However, the target country's alliance to guarantee extended deterrence does not keep the challenger from escalating the dispute. Huth argues that this is simply because the target's alliance partner does not have military presence on the targeted territory nor can the partner easily mobilize their forces to defend its ally. ${ }^{20)}$ South Korea, where the United States maintains its troops, is an exceptional case among the cases treated in his study.

Territorial settlement concluded prior to 1950 in the form of written agreement and resulted in clearly delimiting border relations (variable prior settlement) play a significant role in restraining the initiation of border disputes. Otherwise, relevant countries show more tendencies to initiate territorial disputes. While the former three variables are deduced from the realist theories, this last one belongs to the idealist arguments.

\section{International Experience Factors in Domestic Context}

Variables in this group are external factors that should be processed in the specific domestic decision-making process. Due to space constraints, only those variables applicable to the three territorial disputes in Northeast Asia are discussed here. First, even these days, decolonization norm is valid for dispute initiation. There are calls for apologies to countries with imperialist histories for their wrongdoings they committed during the colonial period. The decolonization norm also affects the behavior of countries that had been colonized in the past. Second, a country with a memory of a prior loss of territory to a given country tends to have a biased view on the territorial relationships with that country (variable prior loss of territory). Memory of territorial loss may also influence a country's national identity and historical memory, influencing

19) Huth (1998).

20) Huth (1998). 
a country's foreign policy decision-making.

Memories of frustration from the conflict of lesser degree than the loss of territory are found to have their own influence on the territorial conflict behavior. Previous stalemates in negotiations tend to make disputes escalate into armed conflicts, and experience of prior military conflict not only makes the escalations easy, but also the peaceful resolution more probable. Past defeat in armed conflict restrains the tendency of escalation and urges for peaceful resolution once the dispute breaks out. Prior experience of unsettled dispute in other areas holds back the decision makers and the citizens from initiating a territorial dispute. Contrary to the memories of the past, the current domestic estimation on the changes in status quo also affect the decision-making process. The judgment may cause a country to rush for escalation of the dispute.

Comparing the two groups of variables above, Huth comments that "the reason why foreign policy leaders adopt or maintain policies that risk conflict with other states is driven in large part by domestic political concerns... Military security-issues may be close to being sufficient conditions for conflict and rivalry between the states but no means are they necessary conditions." ${ }^{21)}$

\section{Domestic Variables in the Democratic Peace Thesis}

Studies on the variables of domestic decision-making process in this subject began to incorporate hypotheses from the democratic peace thesis, which succeeded in empirically demonstrating the fact that a democracy never fights another democracy. ${ }^{22)}$ Two models are used to explain the domestic process: the political accountability mode ${ }^{23)}$ and the political leadership model. ${ }^{24)}$ In both models, political leaders are assumed to pursue national security interests while seeking tenure and position of political power in the domestic arena. Because retaining office is the primary goal of the incumbent leaders, they tend to consider all of the aforementioned factors. The demands of political accountability are more intense in democratic societies than in non-democratic societies. Political leaders in democracies tend to consider variables of international context in the domestic political nexus.

The higher the challenger's level of democracy is, the lower the tendency is for it to challenge the status quo. It also decreases the probability that the challenger would

21) Huth (1998), p. 183.

22) See Maoz and Russett (1993), Bueno de Mesquita and Lalman (1992), and Rummel (1983).

23) Huth and Allee (2002b), pp. 754-90.

24) Chiozza and Choi (2003), pp. 251-78. 
make decisions to escalate the situation into an armed conflict. Even though the challenger's level of democracy does not affect its decision to make concessions, it does have a positive impact on it. In particular, a signal of resolve from the democratic target country has a significant influence on decision-makers in keeping them from escalating the situation into an armed conflict and making them more inclined to undertake negotiations and concessions. These results illustrate the importance of regime types in the development of territorial disputes.

The other two variables have to do with the characteristics of leadership in a democratic society. The strength of the ruling coalition on the challenger's side makes a statistically significant and marginally important impact on conflict escalation and peaceful resolution. On the other hand, the strength of the ruling coalition of the target country does not play an important role.

The second leadership-related variable is the amount of time that has past after an election. Hypotheses on this variable examine whether leaders who have assumed power recently find themselves in a better position to pursue peaceful resolution on existing territorial disputes. The new leader hypothesis suggests that a recently-elected leader is more likely to opt for a peaceful resolution because as time goes by, it becomes increasingly more difficult to opt for a policy option that disrupts the existing balance of power among domestic political actors. The seasoned leader hypothesis, on the other hand, contends that a leader who has been in office for a longer period of time is more likely to opt for decision for a peaceful resolution. In general, data analysis supports the new leader hypothesis. Whether the method is non-violent or violent, political leaders of the challenger country are more likely to challenge the status quo during the early period of the term in power. However, the probability of a dispute escalating into an armed conflict rises as the time in office of the target country's leader gets longer. This shows that the political leadership has a tendency of becoming increasingly reliant on existing conservative forces in its policy decisions as more time elapses from the previous election and a new election approaches.

\section{Variables Concerned with Peaceful Resolution}

All the variables mentioned above and the results of their statistical analyses can be used to predict the future course of current disputes and the probability of their peaceful resolution. The variables can be divided into two groups according to the possibility of control. The balance of military force and the existence of a common alliance between the challenger and the target can be changed only by the mid- to long-term national 
strategies of the respective countries. ${ }^{25)}$ Extended deterrence does not work in territorial disputes because, in many cases, the foreign ally forces are not near the disputed territory.

None of the international experience factors in domestic context can be utilized as policy tools for a peaceful resolution to territorial disputes. This is because international experience factors are embedded in national histories. The variables should be filtered through domestic political regimes, during which the principles of democratic peace exert their influence. Even though the level of democracy in the third group is not readily amenable to political control, signal of resolve and strength of ruling coalition are variables whose value may vary in a relatively short time.

\section{Test on Territorial Matters in Northeast Asia}

The three disputed areas in Northeast Asia are Dokdo/Takeshima, Senkaku/Diaoyutai, and the Northern Territories of Japan. ${ }^{26)}$ The variables discussed in the previous section for their statistical significance will be applied to each of these three cases of territorial disputes to examine the validity of the hypotheses and the probability of the three disputes being resolved peacefully.

\section{Case 1: Dokdø/Takeshima}

An alliance between Korea and Japan has been discussed on and off in the academic community as a means to augment either country's national security. ${ }^{27)}$ The relationship between the two countries can be described, at best, as an "alignment despite antagonism." ${ }^{88)}$ The two countries are able to maintain even this tenuous a relationship because of U.S. mediation. Currently, the region does not have an organization founded on common alliance relationships that can serve as a mechanism for dispute resolution. Northeast Asia also lacks a regional security community. It means that interstate politics of this region is suffering from a lack of mutual trust. Taking any issue to the International

25) See Gibler (2007), pp. 509-32; and Douglas M. Gibler, "Alliances That Never Balance: The Territorial-Settlement Treaty," in Paul Diehl (ed.), A Road Map to War: Territorial Dimensions of International Conflict (Nashville: Vanderbilt University Press, 1999), pp. 181-204.

26) Dokdo is Korean and Takeshima in Japanese. Senkaku is Japanese and Diaoyutai is Chinese. 'Northern territories' is the Japanese expression for the 'South Kuril Islands' of Russia.

27) As an example, see Choi Woondo, "Changes in Japanese Defense Policy and Their Implications on Korean National Security," National Strategy 9-2 (2003), pp. 87-118.

28) Victor D. Cha, Alignment Despite Antagonism: The US-Korea-Japan Security Triangle (Stanford: Stanford University Press, 1999). 
Court of Justice (ICJ) requires an agreement between the challenger and the target country. As long as the zero-sum perception on national interest dominates the regional politics, the ICJ cannot have a role to play in the territorial disputes of the region. However, Korea and Japan had been aligned in the same camp through respective alliances with the United States. Military balance has not been a major factor in the Korea-Japan territorial dispute because of this 'quasi-alliance' relationship.

Table 1 shows that the strategic value of the territory was important in all three stages of the dispute: initiation, escalation, and negotiation. According to a study, ${ }^{29)}$ strategic value of Dokdo/Takeshima and the Northern Territories of Japan are rated 'intermediate', while Senkaku/Diaoyutai is rated 'high'. The rate is 'high' if the territory fulfills both of the following conditions: desired geopolitical location and a reserve of a strategic resource. If a territory fulfills only one condition, it is considered 'intermediate,' and 'low, if it fulfills neither. The debate over the economic value of Dokdo/Takeshima focuses on fishing, minerals, and resources. While resource reserves around Dokdo/Takeshima are still under investigation, the statistical analyses discussed in the previous section have demonstrated that a territory's economic value plays only a minor role in the course of a territorial dispute.

Among the international experience factors in domestic context, three variables are marked significant for the initiation of dispute. The variables of prior loss of territory and decolonization norm have validity for the Dokdo/Takeshima case. When President Syngman Rhee declared the Peace Line in 1952, it was partially due to the Korea's antagonism toward Japan, which stems from the colonial experience (loss of territory). The Peace Line remained in force until 1965 only to be repealed with the conclusion of the Korea-Japan Fisheries Agreement. The unilateral declaration of the Peace Line was possible without armed conflict partially due to the decolonization norm of the post-war period. Ever since then, Japan has been the initiator in each round of dispute. In dispute escalation, only one factor of stalemates in negotiations is applicable to the Dokdo/Takeshima case. Speech blunders by Japanese politicians and disputes over matters of history awaken a sense of national identity in Koreans and invited the same sense of frustration which the variable does.

What about the variables in the political accountability thesis? Since the declaration of the Peace Line in 1952, Japan has been the challenger in each dispute episode, especially during the 1990s. In dispute initiation, the challenger's democracy level is

29) Bae Jinsoo, "Analysis of Dokdo/Takeshima Dispute from the Perspective of International Conflict: Application of Measurement and Index Building" (in Korean), Journal of Dispute Resolution 4-1 (2006), pp. 25-56. 
supposed to have a restraint effect. This is obviously not applicable to Japan, which is a democracy but plays the role of the challenger in the Dokdo/Takeshima disputes. However, because both the challenger (Japan) and the target (Korea) are democratic societies, ${ }^{30)}$ the new leader hypothesis tells that dispute initiation should occur during the later periods of political leaders' tenures. Major concessions or a conciliatory approach, which mark a departure from the usual handling of territorial matters - dominated by conservative forces - should be possible only during the early period right after an election in the respective countries. This hypothetical pattern accords with the reality of Korea, but the relationship between dispute initiation and the electoral cycle in Japan must be subject to a more rigorous statistical analysis. ${ }^{31)}$

In terms of dispute escalation, Japan's high level of democracy and democratic Korea's signal of strong resolve must have militated against escalatory interactions. The variable of strength of ruling coalition and the variable of the time elapsed since the last election can be estimated to be valid in Japan and Korea respectively in explaining the aggravation of disputes. However, it also requires rigorous statistical analysis.

\section{Case 2: Senkaku/Diaøyutai Islands}

Whether the Japanese claim that Japan began to legally occupy Senkaku/Diaoyutai Islands from 1985 is valid or not, Chinese claim over the islands started from 1969, right after the existence of natural resources in the sea-bed of the area were discovered. From this fact, we can say China was the challenger at that point in time.

The strategic value of Senkaku/Diaoyutai is rated 'high' in the aforementioned Bae's analysis. ${ }^{32}$ By definition, the 'high' value includes economic value and strategic value of the territory. Even though there was imbalance in strategic armaments in favor of China, comprehensive military balance between Japan and China in terms of deterrence was estimated to be in parity. Between the two groups - Japan on one side and China, Taiwan, and Hong Kong on the other side-there is no common alliance tie. Northeast Asia does not have a regional security community. The former two variables of economic

30) According to one report which developed the index of democracy, Japan was ranked as 20th, and categorized in the Full Democracy group. Korea was ranked as 31st, in the Flawed Democracy group which ranges from 29th to 81st in the whole list of 167 countries. Russia was the 102nd in the Hybrid Regime group (83nd 111th). China was ranked 138th in the Authoritarian Regime group. See Laza Kekik "The Economist Intelligence Unit's Index of Democracy" (2007), http://www.economist.com/media /pdf/Democracy_Index_2007_v3.pdf.

31) Introductory empirical test is done in Yi Sungwoo, Conflict Behavior in Korea-Japan Relations: Generality vs. Peculiarity, Final Report for Project on Peace Index of Northeast Asia (2008).

32) Bae (2006), pp. 25-56. 
and strategic value of territory and balance of military forces were inviting the initiations of disputes over this territory but the variables concerned with alliance to keep the possibility of initiation in check did not exist. The three kinds of variables worked in the same directions in dispute escalation. On the contrary, however, for a peaceful resolution, there was no variable that raised the probability of it.

The international experience factors in domestic context show a pattern similar to that of the Dokdo/Takeshima case. Among the variables in this group, the only factor that contributes to dispute escalation in the Senkaku/Diaoyutai case is decolonization norms. In explaining dispute escalation, frustration from repetitive provocations over historical issues might have had the same effect as the variable of stalemates in negotiations. On the side of China, the variable of prior military conflict should have valid effect on its escalation of disputes but prior military defeat which occurred long ago could not constrain China, which might have perceived the changes in status quo. The last two variables which were supposed to promote peaceful resolutions cannot be estimated to have worked as expected by the hypotheses. In this second group of variables, there were no factors working to promote reconciliation between China and Japan.

Among the political accountability factors, variables concerned with leadership and election should be subject to statistical testing in order to reveal the true impact on dispute. China, however, is an authoritarian regime. This regime type does not guarantee peaceful resolution of dispute. Japan's signal of resolve to respond in kind, combined with its high level of democracy tempers tendencies toward dispute escalation.

The degree of trust between Japan and China is lower than that between Korea and Japan which are aligned under their respective alliance with the United States. The intangible value of a territory reflects the humiliation of the colonial experience. Therefore, the intangible value of the islands to China, Taiwan, and Hong Kong should be similar to the intangible value that Dokdo/Takeshima holds for Korea. While the islands are valued highly both in terms of their tangible and intangible qualities, there were no variables (e.g., common security ties and challenger democracy level) that can keep a dispute from escalating into an armed conflict. Therefore, if Japan is not prudent, this case has the potential of blowing up into a very dangerous situation. ${ }^{33)}$ In sum, while the strategic location of the islands and historical experience of the nations involved induce disputes over the islands, the balance of power and Japan's level of democracy work against the strong tendency of escalation and encourage negotiations and concessions.

33) See INSS Special Report, "Sino-Japanese Rivalry: Implications for U.S. Policy" (2007). 


\section{Case 3: Northern Territories of Japan}

Japan and Russia do not have a common alliance and the Northeast Asian region lacks a regional security community. The most similar mechanism or framework to regional security organization is the Six Party Talks, whose mission is confined to tackling the North Korean nuclear issue. On the strategic value of the South Kuril Islands to Russia, Yun emphasizes both their economic and military importance. ${ }^{34)}$ Recently, residents of the islands have been planning to develop business and trade relations with foreign countries. Militarily, the islands provide forward air-defense screen and ice-free access for Russian submarines from the Sea of Okhotsk to the Pacific Ocean. In particular, Etorufu and Kunashiri are the gateways to the Sea of Okhotsk for Russian nuclearpowered ballistic-missile submarine fleets. As a whole, however, Bae estimated that the islands' strategic value is 'intermediate.' ${ }^{35)}$ In terms of the military balance of power, Russia was vastly more powerful than Japan during the Cold War period. This advantage must have been effective in defending against Japan's challenges and Japan's behavior for escalation.

Considering all the international political factors, the chances of dispute initiation are relatively small. Apart from the strategic value of the islands, there are no other significant potential catalysts for escalation either. At the same time, the issue does not demonstrate any conspicuous signs that point to a peaceful resolution either.

Among the variables of the international experience factors in domestic context, stalemates in negotiations is the only one applicable to this dispute. Even though there have been numerous offers by the political leaders of the former Soviet Union and today's Russian and several consultations between the two countries on the transfer of two islands - Shikotan and Habomai - to Japan, Japan has continued to insist on the full transfer of all four islands despite the failure to conclude a peace treaty.

Because Russia has become a hybrid regime in the post-Cold War period, not many domestic variables are applicable to this case. Because Japan is ranked very high in the level of democracy and labeled as a challenger in this dispute, the variable of challenger democracy can serve to dampen dispute escalation. Yun, however, suggests several variables, which could be categorized under "political accountability factors," as reasons for Russia's refusal to accept Japan's demand for a full transfer. ${ }^{36)}$ First, the current

34) Yun Yeongmi, "An Analysis of the Main Difficulties for Russian Transfer Ownership of the Kuril Islands to Japan in the Post Soviet Period," Korean Political Science Review 39-4 (2005), pp. $175-297$.

35) Bae (2006), pp. 25-56. 
Russian Constitution requires a national referendum for any decision regarding territorial changes. According to opinion polls conducted in the 1990s regarding the transfer of the four South Kuril Islands, only 14 percent of Russians favored the transfer in 1991 while this figure dwindled further to 7 percent in 1998. Second, a 1993 survey of the residents of the four islands found that only 18 percent to 37 percent favored the transfer as opposed to 52 percent to 78 percent that were against it (except in Shitokan, where the only 26 percent was against).

Another point to note is that Japanese political leadership exhibited clear patterns of the new-leader hypothesis. Adhering to the full-transfer of the islands, Japan maintained its intransigent attitude toward Russian suggestions for economic cooperation. Japan's policy toward Russia underwent two changes during the 1990s. In 1993, Prime Minister Hosokawa gave up the linkage strategy between politics and economy, and allowed room for a two-track (political contention and economic cooperation) policy. He opted for this flexible policy immediately after taking office with the highest-ever approval rating and as the first prime minister from a non-LDP (Liberal Democratic Party) coalition government. With the two-track policy as the framework, Hashimoto pursued more wide-ranging cooperation with Russia, calling it a "multi-dimensional" approach. Opinion polls performed before he was elected as prime minister showed that he had the highest approval rating ever among all candidates for prime minister in Japan's history. These two episodes support the hypotheses on political accountability. ${ }^{37}$

On the whole, however, we can conclude that international factors were the dominant influence on the dispute behavior of Japan on the Northern Territories. Compared to the great chess games among the major powers, the dispute over the four islands is a relatively minor problem that should not upset the basic regional political framework.

\section{Conclusion}

In comparing the results of the statistical analyses with the realities of the three cases of territorial disputes in Northeast Asia, we can see that there are notable differences among them. The cases of the Northern Territories and Senkaku/Diaoyutai Islands depend more on the variables of international political factors than the Dokdo/ Takeshima

36) Yun (2005), pp. 175-297.

37) Kim Jinki, "Comparative Study on the Japanese Government's Approach to Territorial Disputes" (in Korean), Journal of International Regional Studies 9-1 (2005), pp. 22-45 provides a good illustration of the political accountability. 
case does. The balance of military forces and deterrent alliance ties affect the dispute behavior in reality but it is contrary to the findings of Table 1. Even though the balance of military forces is not in Japan's favor, Japan was the challenger on the Northern Territories. The extended deterrence of the United States might have played an important role in Japanese behavior on the islands but previous statistical analysis did not assign a statistical significance on the variable. In general, however, the variables in the international experience factors in domestic context are less applicable to the three cases in Northeast Asia. Due to the repetitive occurrences of episodes in each dispute, stalemates in previous negotiations brought about the frustrations and worked as stimulant for dispute escalation. The only other relevant variables in this category are prior loss of territory and decolonization norms, which are applicable only to explaining the dispute initiation in the Dokdo/Takeshima and Senkaku/Diaoyutai cases.

Among political accountability factors, variables concerned with the electoral cycle cannot be evaluated until rigorous statistical analyses are undertaken. As for the remaining variables, they are more applicable to the Dokdo/Takeshima case than to the other two cases because China and Russia are not evaluated as democratic regimes. In the Dokdo/Takeshima case, the target democracy level, along with the signal of resolve, is vital to containing the dispute's escalation and bringing about a peaceful resolution. However, the challenger's democracy level is actually responsible for dispute initiation and escalation. This is contradictory to what Japan as a democratic regime actually does for the Dokdo/Takeshima case.

The findings of the analyses can be used to formulate policy suggestions. Let us take the Dokdo/Takeshima case as an example. At the domestic level, the promotion of democracy is necessary for the peaceful settlement of the dispute, and signaling a firm resolve in a crisis situation is important in preventing the escalation of the dispute into an armed conflict. At the international level, alliance ties with the United States acted as a deterrent against dispute escalation between Japan and Korea, and maintaining a balance in military forces contribute to peaceful resolution of the dispute. Even though the validity is not tested for the disputes in Northeast Asia, previous studies suggest that a regional security community, which does not exist in Northeast Asia, will make a most comprehensive influence for peaceful resolution on the whole life cycles of the three territorial disputes. 


\section{REFERENCES}

Bae, Jinsoo. "Analysis of Dokdo/Takeshima Dispute from the Perspective of International

Conflict: Application of measurement and Index Building" (in Korean). Journal of Dispute Resolution, 4-1 (2006), pp. 25-56.

Bueno de Mesquita, Bruce and David Lalman. War and Reason. New Haven: Yale University, 1992.

Bueno de Mesquita, Bruce, Alastair Smith, Randolph Siverson, and James D. Morrow. Logic of Political Survival. Cambridge: MIT Press, 2003.

Cha, Victor D. Alignment Despite Antagonism: The US-Korea-Japan Security Triangle. Stanford: Stanford University Press, 1999.

Chiozza, Giacomo and Ajin Choi. "Guess Who Did What: Political Leaderships and the Management of Territorial Disputes, 1950-1990.” Journal of Conflict Resolution 47-3 (2003), pp. 251-78.

Choi, Woondo. "Changes in Japanese Defense Policy and Their Implications on Korean National Security.” National Strategy 9-2 (2003), pp. 87-118.

Diehl, Paul F. (eds.). A Road Map to War: Territorial Dimensions of International Conflict. Nashville: Vanderbilt University Press, 1999.

Doyle, Michael. "Liberalism and World Politics." American Political Science Review 80-4 (1986), pp. 1151-61.

Gibler, Douglas M. "Bordering on Peace: Democracy, Territorial Issues, and Conflict." International Studies Quarterly 51-1 (2007), pp. 509-32.

. "Alliances That Never Balance: The Territorial-Settlement Treaty," in Paul Diehl (eds.), A Road Map to War: Territorial Dimensions of International Conflict. Nashville: Vanderbilt University Press, 1999.

Goertz, Nils P. and Paul Diehl. Territorial Changes and International Conflict. London: Routledge, 1992.

Hensel, Paul R., Sara M. Mitchell, Thomas E. Sowers II, and Clayton L. Thyne. "Bones of Contention: Comparing Territorial, Maritime, and River Issues." Journal of Conflict Resolution 52-1 (2008), pp. 117-43.

Huth, Paul K. "Extended Deterrence and the Outbreak of War." American Political Science Review 82-2 (1988), pp. 423-43.

. Standing Your Ground: Territorial Disputes and International Conflict. Ann Arbor: Michigan University Press, 1998. 
Huth, Paul K. and Todd Allee. The Democratic Peace and Territorial Conflict in the Twentieth Century. New York: Cambridge University Press, 2002a.

. "Domestic Political Accountability and the Escalation and Settlement of International Disputes." Journal of Conflict Resolution 46-6 (2002b), pp. 754-90.

INSS Special Report. "Sino-Japanese Rivalry: Implications for U.S. Policy.” 2007.

Kekic, Laza. "The Economist Intelligence Unit's Index of Democracy," (2007) http://www.economist.com/media/pdf/Democracy_Index_2007_v3.pdf.

Kim Jinki. "Comparative Study on the Japanese Government's Approach to Territorial Disputes" (in Korean). Journal of International Regional Studies 9 (2005), pp. 22-45.

Ko, Sangdoo, Choi Woondo, and Yoon Taeyoung. "Conflict Management in the PostCold War Era: Preventive Diplomacy and PKO.” The Korean Journal of Defense Analysis 17-2 (2005), pp. 35-62.

Maoz, Zeev and Bruce Russett. "Normative and Structural Causes of Democratic Peace, 1946-1986." American Political Science Review 87-3 (1993), pp. 624-38.

Smith, Dan. "Trends and Causes of Armed Conflicts" (Berghof Foundation, 1999), www.berghof-handbook.net/articles/smith_handbook.pdf.

Rummel, R. J. "Libertarianism and International Violence." Journal of Conflict Resolution 27-1 (1983), pp. 27-71.

Tir, Jaroslav. Redrawing the Map to Promote Peace: Territorial Dispute Management via Territorial Changes. Lanham: Lexington Books, 2006.

Vasquez, John A. The War Puzzle. Cambridge: Cambridge University Press, 1993.

Vasquez, John A. "Mapping the Probability of War and Analyzing the Possibility of Peace: The Role of Territorial Disputes." Conflict Management and Peace Science 18-2 (2001), pp. 145-73.

Yi, Sungwoo. Conflict Behavior in Korea-Japan Relations: Generality vs. Peculiarity. Final Report for Project on Peace Index of Northeast Asia, 2008.

Yun, Yeongmi. "An Analysis of the Main Difficulties for Russian Transfer Ownership of the Kuril Islands to Japan in the Post Soviet Period." Korean Political Science Review 39-4 (2005), pp. 175-297. 